\title{
The Effectiveness Learning of Physical Education on Pandemic COVID-19
}

\author{
Sumbara Hambali, ${ }^{1, *}$ Asep Akbaruddin ${ }^{2}$, Domi Bustomi ${ }^{3}$, Achmad Rifai ${ }^{3}$, Tatang Iskandar ${ }^{3}$, \\ Azi Faiz Ridlo ${ }^{3}$, Yopi Meirizal ${ }^{1}$, Ruslan Rusmana ${ }^{1}$, Rury Anggoro Tyas ${ }^{1}$ \\ ${ }^{1}$ Department of Physical Education, Health and Recreation, STKIP Pasundan, 40512, Cimahi, Indonesia \\ ${ }^{2}$ Department of Physical Education, Health and Recreation, STKIP Subang, 41211, Subang, Indonesia \\ ${ }^{3}$ Department of Physical Education, Health and Recreation, Universitas Islam 45 Bekasi, 17113, Bekasi, Indonesia
}

Received September 22, 2020; Revised November 20, 2020; Accepted November 27, 2020

\section{Cite This Paper in the following Citation Styles}

(a): [1] Sumbara Hambali, Asep Akbaruddin, Domi Bustomi, Achmad Rifai, Tatang Iskandar, Azi Faiz Ridlo, Yopi Meirizal, Ruslan Rusmana, Rury Anggoro Tyas, "The Effectiveness Learning of Physical Education on Pandemic COVID-19," International Journal of Human Movement and Sports Sciences, Vol. 9, No. 2, pp. 219-223, 2021. DOI: 10.13189/saj.2021.090208.

(b): Sumbara Hambali, Asep Akbaruddin, Domi Bustomi, Achmad Rifai, Tatang Iskandar, Azi Faiz Ridlo, Yopi Meirizal, Ruslan Rusmana, Rury Anggoro Tyas (2021). The Effectiveness Learning of Physical Education on Pandemic COVID-19. International Journal of Human Movement and Sports Sciences, 9(2), 219-223. DOI: 10.13189/ saj.2021.090208.

Copyright $\mathrm{C} 2021$ by authors, all rights reserved. Authors agree that this article remains permanently open access under the terms of the Creative Commons Attribution License 4.0 International License

\begin{abstract}
In some countries, the COVID-19 pandemic has become a major disaster that has caused several areas to experience serious problems. One of them is the field of education, which requires online learning. However, this is effective? The purpose of this study was to determine the effectiveness of online learning during the COVID-19 pandemic. The object of this research is the Effectiveness Learning of Physical Education in the Pandemic COVID-19 at West Java Elementary School. This study aims to reveal field data by explaining what is revealed in the field, analyzing and concluding the results of the research. This research uses descriptive research with the process of collecting and compiling data, as well as analyzing and interpreting the data. The sample used is the West Java Elementary School, such as Bandung City, Cimahi City, Subang City, Bekasi City and Karawang City. The data collection technique in this study used a google form questionnaire that was sent through the WhatsApp application group through the homeroom teacher. After collecting data using a questionnaire, it can be seen that the effectiveness of the Physical Education Learning at the time of the COVID-19 Pandemic was at a score of 50\%. This means that physical education learning carried out online is still not optimal. Students and teachers must be able to better adapt to the implementation of the online Physical Education learning process.
\end{abstract}

Keywords Effectiveness Learning, Physical Education, Pandemic COVID-19

\section{Introduction}

In Indonesia, physical education is a subject that is given at every level of education, with the aim that students acquire various movement skills, knowledge of the concept of physical health and also various social attitudes. This subject has the objective of improving and developing aspects of knowledge, attitudes and movements [1] Physical education is an important context in promoting physical activity and increasing learning motivation among young people [2] Basically physical education learning was born to help realize the goals of education, because it can develop all aspects that students have, namely cognitive, affective and psychomotor. [3] Of course, the activities given in physical education lessons must be in accordance with the characteristics of students, because so that the potentials of these students can develop, especially their fitness. Being in a fit body can provide short-term and long-term benefits to academic achievement [4] In addition, physical education is closely related to physical activity, where physical activity carried 
out regularly has a tremendous impact on health. Especially during the COVID-19 pandemic, many people were infected through their respiratory tract due to pathogens. This is where physical activity can improve pathology [5], [6] Although there are statements that during the COVID-19 pandemic, physical activity and exercise can play a positive and negative role in individual health [7]

But now, especially in Indonesia, the learning process in schools has stopped completely. This was caused by a case of the spread of the COVID-19 virus. During this pandemic, several activities were forced to close globally, including educational activities, and this was a tremendous crisis response to the learning process that migrated to online learning which functions as an educational platform [8] Online learning is the use of the internet and several other important technologies in developing materials for educational purposes, instructional delivery and management programs [9] This is what makes the physical education learning process a little less effective, especially the learning process, which is almost all done in practice. Even though physical education learning is learning that is interesting and fun, and easy to understand because it is carried out directly in the field [10] To obtain positive and long-term learning outcomes, students should use effective learning strategies, for example taking practical tests or spacing study sessions over time [11]. The effectiveness of learning is a measure of the success of the learning process activities to achieve learning objectives [12] This is what causes some anxiety in the majority of physical education teachers, who require that the learning process be kept online.

Online learning is learning using an internet network with accessibility, connectivity, flexibility and the ability to generate various types of interactions in learning [13] Some of the media used in online learning include smartphones, laptops, computers, tablets, iPhones and several other devices that can access information at any time [14] this is also needed in learning the era of the industrial revolution 4.0 [15]. These various explanations make all the lessons that are given in schools, including physical education subjects, be given online as well.

However, another problem is about the facilities used during the online learning process, especially for students, because there are still students who are not familiar with the internet, and how to operate various platforms on online media. Effective learning describes students who are active during the learning process. Learning to read or listen will make learning more effective, that is, if you want to realize learning goals, students must learn based on experience [16] Therefore, during this online learning period, how much effectiveness would physical education learning be during the pandemic COVID-19?

\section{Objectives}

The focus in this research is on the effectiveness of physical education learning conducted online during the COVID-19 pandemic. The research subjects were fifth grade elementary school students in West Java, scattered in various cities, such as Bandung, Cimahi, Subang, Bekasi and Karawang, with a total of 140 respondents.

\section{Methods}

The method in this research is descriptive, which aims to provide an overview of real information that is being experienced directly by the research subject [17] The population in this study were all fifth grade elementary school students in West Java. The sample used was 140 grade five elementary school students in West Java, consisting of Cimahi City, Bandung City, Subang City, Bekasi City and Karawang City, each city consisting of 28 students. The sampling technique used cluster random sampling. The instrument used was a questionnaire on the effectiveness of physical education learning which was focused on the use of online media used, knowledge about COVID-19 and physical education subject matter, using a Likert rating scale, namely Strongly Agree (SS), Agree (S), Disagree (TS), Strongly Disagree (STS) which is made in the form of a google form with the url address as follows: https://bit.ly/efeksiPjj through the homeroom teacher. The data analysis technique uses descriptive analysis with a percentage formula with the following formula:

$$
P=\frac{\sum X_{1}}{\sum X_{n}} \times 100 \%
$$

Information:

$\mathrm{P}=$ Amount or amount of percentage

$\sum X_{1}=$ The actual score total

$\sum X_{n}=$ The ideal score

To provide criteria for the percentage of data obtained, the author refers to the explanation. Arikunto provides the following assessment criteria:

Table 1. Assessment Criteria [18]

\begin{tabular}{|c|c|}
\hline Criteria & Percentage \\
\hline Very Well & $80 \%-100 \%$ \\
Well & $66 \%-79 \%$ \\
Enough & $56 \%-65 \%$ \\
Not Good & $40 \%-55 \%$ \\
Very Not Good & $30 \%-39 \%$ \\
\hline
\end{tabular}




\section{Result}

Based on the results of research that has been conducted by providing a questionnaire about the effectiveness of physical education learning during the COVID-19 pandemic, the following results are obtained:

Table 2. Results of the Respondents Questionnaire Score

\begin{tabular}{|c|c|c|}
\hline No & Jawaban & Jumlah Skor \\
\hline 1 & SS & 3500 \\
\hline 2 & S & 3720 \\
\hline 3 & TS & 1180 \\
\hline 4 & STS & 475 \\
\hline \multicolumn{2}{|c|}{ Total Score $\left(\mathrm{X}_{1}\right)$} & 8875 \\
\hline \multicolumn{2}{|c|}{ Maximum Score $\left(\mathrm{X}_{\mathrm{n}}\right)$} & 17750 \\
\hline \multicolumn{2}{|c|}{$\%$} & $50 \%$ \\
\hline
\end{tabular}

Based on table 2, it can be seen that of the total respondents, the percentage of the effectiveness of physical education learning during the COVID-19 pandemic is at a score of $50 \%$. This means that the physical education learning process that is carried out online falls into the poor category.

\section{Discussion}

The results of the study on online learning during the COVID-19 pandemic focused on several indicators such as the use of online learning media, teaching materials provided, knowledge of the COVID-19 virus, and the learning process related to material on physical education. In the indicators of using online learning media, some students are already quite able to operate it or have been given it well enough and in accordance with the students' abilities, even though in fact it still has to be supervised by parents. The implementation of online learning in elementary schools has been carried out quite well, but there must be cooperation between teachers, students and parents of students [19] From the data in the field, the application media that is often used in online learning in elementary schools is the WhatsApp group. This application is also currently widely used as a collaborative application, so that e-learning can be optimized [20]. Evaluation in each process and learning tools can solve learning problems[21]. This application is considered a suitable medium to be use in elementary schools, because of its characteristics that are a little easy to use in conveying material, but it must be kept under parental supervision so that it is not used outside the learning process, because this application also allows it to be the influence of the lack of student discipline [22].

Whereas in the teaching material indicators provided, the results obtained from the respondents' answers were quite good. This means that the material presented to students through online learning can be understood and carried out by students, because the provision of material is carried out in stages. Because the material provided does not need to be given in full, but in the form of a stimulus in crossing students so that they are able to achieve the competencies that must be mastered [23] Students will experience the learning process well if they are actively able to instruct their own understanding from the lessons learned [24] Not all students will be successful after doing online learning, because is due to the learning environment and the characteristics of the students themselves [25]

Then the indicators of knowledge of the COVID-19 virus still tend to be low, there is because elementary school students do not know specifically about this type of virus. Basically, people really need education about health related to the COVID-19 virus [26] However, in the prevention procedures, most of them already know this cannot be separated from the role of parents who always provide advice and suggestions on procedures for a healthy lifestyle to avoid viruses and bacteria.

Finally, the indicators regarding the physical education learning process, especially the material presented, get quite good scores, even though the material presented is a little less optimal. Therefore, there are many students who want the physical education learning process to be immediately implemented directly, because it is felt to be less effective, especially in terms of assignments and assessments, which are a bit troublesome for both teachers and students and parents.

Online learning is one way to anticipate breaking the chain of spread of the COVID-19 virus. This is also an appeal from the government directly through its circular that the Ministry of Education and Culture prohibits direct face-to-face learning and orders to carry out online learning, schools are required to provide learning or assignments online to students [27] In fact, online learning has become a demand in the world of education since the last few years [28] This is because online learning is indeed able to have a positive influence on improving students' cognitive abilities, students often open reading through online media and this is of course the more information they get. [29], [30]

However, based on the results of research that has been conducted, physical education learning that is carried out online is even less effective. This is because the physical education learning process which requires students to be directly involved in the field has not been realized. Especially at the elementary school level, the learning process should be done directly so that students better understand the concept of motion and play. Another difficulty at the elementary level is the use of online media, at the college or secondary level there may be a little problem, but at the basic level, which usually carries communication tools such as cellphones prohibited [31] Not to mention that the network problem tends to be 
unstable, especially in rural areas, which makes online learning a bit constrained. There are at least four obstacles experienced by the world of education in carrying out the learning process during the COVID-19 pandemic, namely: 1) Limited internet mastery for teachers; 2) Inadequate resources and infrastructure; 3) Limited internet access; 4) Funds are still not ready for emergency situations [32] Another limitation of bold learning is the problem of internet connection or signals from students, which make the material download process and hinder the smooth learning process [33]

In addition, the physical education learning process emphasizes physical aspects, elements of fitness, health, games, sports and recreation [34] so it is not done optimally if done online. In fact, the learning process is carried out in an open space or field, using deductive methods, demonstrations, assignments and a little understanding [35], not to mention the lack of internet access and the operation of online features have made physical education subjects encounter a few obstacles and obstacles during the COVID-19 pandemic. Especially for physical education teachers who teach in special schools, they will definitely experience obstacles in the implementation of their practice, as well as inadequate facilities and infrastructure, making teachers tend to be confused in teaching physical education. [36]

However, on the other hand, there are several positive impacts if this online learning is carried out optimally. Some of them are about the learning process that is fully centered on students, making students more independent, more flexible time and broader in expression, making students more creative in displaying their potential. [37] Besides, students will be better prepared to prepare for learning, evaluate, organize and indirectly maintain their learning motivation [38], [39]

\section{Limitations}

One limitation that is of considerable concern is the number of population which is still limited to the scope of one province. This is still far from the number of provinces in Indonesia. So this research may only provide an overview and impact on one area and scope at the primary school level on how much the effectiveness of physical education learning is. Therefore, studies at a higher level, more broadly and using instruments that are more suitable for each level of education may be much better and have a greater impact on providing information about the effectiveness of physical education learning in Indonesia.

\section{Conclusions}

Based on the results of the research and discussion that has been described, it can be seen that the overall effectiveness of physical education learning in the COVID-19 pandemic is less effective to do. However, every learning process that is carried out is certainly not perfect, there are advantages and disadvantages to each. It remains the duty of an education to be able to facilitate students so that they continue to want to learn. At least for now, the physical education learning process can still be done even though online, this is to reduce the spread of the COVID-19 virus, so that the Indonesian people can returns to normal activities again.

\section{REFERENCES}

[1] A. Sobarna and S. Hambali, "Meningkatkan keterampilan lompat jauh gaya jongkok siswa SD memalui pembelajaran Kids atletik," Prem. Educ. J. Pendidik. Dasar dan Pembelajaran, vol. 10, no. April, pp. 72-80, 2020, doi: 10.25273/pe.v10i1.6189.

[2] J. Timo, Y. Sami, W. Anthony, and L. Jarmo, "Perceived physical competence towards physical activity, and motivation and enjoyment in physical education as longitudinal predictors of adolescents' self-reported physical activity," J. Sci. Med. Sport, vol. 19, no. 9, pp. 750-754, 2015, doi: 10.1016/j.jsams.2015.11.003.

[3] M. L. Kroote and C. A. Bucher, Management of Physical Education and Sport, Twelfth. New York: McGraw-Hill, 2007.

[4] D. M. Castelli, E. Glowacki, J. M. Barcelona, H. G. Calvert, and J. Hwang, "Active Education: Growing Evidence on Physical Activity and Academic Performance," Austin, 2015.

[5] G. Maugeri et al., "The impact of physical activity on psychological health during Covid-19 pandemic in Italy," Heliyon, vol. 6, no. 6, pp. 1-8, 2020, doi: 10.1016/j.heliyon.2020.e04315.

[6] S. A. Martin, B. D. Pence, and J. A. Woods, "Exercise and respiratory tract viral infections," Exerc. Sport Sci. Rev., vol. 37, no. 4, pp. 157-164, 2009, doi: 10.1097/JES.0b013e3181b7b57b.

[7] J. A. Woods et al., "The COVID-19 pandemic and physical activity," Sport. Med. Heal. Sci., vol. 2, no. 2, pp. 55-64, 2020, doi: 10.1016/j.smhs.2020.05.006.

[8] O. B. Adedoyin and E. Soykan, "Covid-19 pandemic and online learning: the challenges and opportunities," Interact. Learn. Environ., vol. 28, no. 7, pp. 1-13, 2020, doi: $10.1080 / 10494820.2020 .1813180$.

[9] K. Fry, "E-learning markets and providers: Some issues and prospects," Educ. + Train., vol. 43, no. 4/5, pp. 233-239, 2001, doi: 10.1108/EUM0000000005484.

[10] A. Suherman, "Implementasi Kurikulum Baru Tahun 2013 Mata Pelajaran Pendidikan Jasmani (Studi Deskriptif Kualitatif pada SDN Cilengkrang)," Mimb. Sekol. Dasar, vol. 1, no. April, pp. 71-76, 2014.

[11] F. Biwer, M. G. A. oud. Egbrink, P. Aalten, and A. B. H. de Bruin, "Fostering Effective Learning Strategies in Higher Education - A Mixed-Methods Study," J. Appl. Res. Mem. 
Cogn., vol. 9, no. 2, pp. 186-203, 2020, doi: 10.1016/j.jarmac.2020.03.004

[12] A. Rohmawati, "Efektivitas Pembelajaran," J. Pendidik. Usia Dini, vol. 9, no. 1, pp. 15-32, 2015.

[13] M. J. L., D.-D. Camille, and K. Galyen, "E-Learning, online learning, and distance learning environments: Are they the same?," Internet High. Educ., vol. 14, no. 2, pp. 129-135, 2011, doi: https://doi.org/10.1016/jiheduc.2010.10.001.

[14] J. Gikas and M. M. Grant, "Internet and Higher Education Mobile computing devices in higher education: Student perspectives on learning with cellphones, smartphones \& social media," Internet High. Educ., vol. 19, pp. 18-26, 2013, doi: 10.1016/j.iheduc.2013.06.002.

[15] R. A. Pangondian, P. I. Santosa, and E. Nugroho, "Faktor Faktor Yang Mempengaruhi Kesuksesan Pembelajaran Daring Dalam Revolusi Industri 4.0," in Seminar Nasional Teknologi Komputer \& Sains (SAINTEKS), 2019, vol. 2, pp. 56-60.

[16] E. J. Wood, "Problem-Based Learning: Exploiting Knowledge of how People Learn to Promote Effective Learning," Biosci. Educ., vol. 3, no. 1, pp. 1-12, 2004, doi: 10.3108/beej.2004.03000006.

[17] Sugiyono, Metode Penelitian Pendidikan, 18th ed. Bandung: Alfabeta, 2017.

[18] S. Arikunto, Prosedur Penelitian Suatu Pendekatan Praktek. Jakarta: Rineka Cipta, 2012.

[19] W. Aji and F. Dewi, "Dampak Covid-19 Terhadap Implementasi Pembelajaran Daring Di Sekolah Dasar," Edukatif J. Ilmu Pendidik., vol. 2, no. 1, pp. 55-61, 2020, doi: 10.31004/edukatif.v2i1.89.

[20] A. Prajana, "Pemanfaatan Aplikasi Whatsapp Dalam Media Pembelajaran Di UIN Ar-Raniry Banda Aceh," Cybersp. J. Pendidik. Teknol. Inf., vol. 1, no. 2, pp. 122-133, 2017.

[21] Muslimin and Destriana, "Evaluation of curriculum implementation of 13 sports and health education teachers," Univers. J. Educ. Res., vol. 8, no. 1, pp. 27-35, 2020, doi: 10.13189/ujer.2020.080104.

[22] E. Suryadi, M. H. Ginanjar, and M. Priyatna, "PENGGUNAAN SOSIAL MEDIA WHATSAPP DAN PENGARUHNYA TERHADAP DISIPLIN BELAJAR PESERTA DIDIK PADA MATA PELAJARAN PENDIDIKAN AGAMA ISLAM," Edukasi Islam J. Edukasi Islam., vol. 7, no. 1, pp. 1-22, 2018, doi: 10.30868/EI.V7I01.211.

[23] A. S. Syarifudin, "IMPELEMENTASI PEMBELAJARAN DARING UNTUK MENINGKATKAN MUTU PENDIDIKAN SEBAGAI DAMPAK DITERAPKANNYA SOCIAL DISTANCING," Met. J. Pendidik. Bhs. dan Sastra Indones. pemerintah, vol. 5, no. 1, pp. 31-34, 2020, doi: https://doi.org/10.21107/metalingua.v5i1.7072.

[24] A. Majid, Perencanaan Pembelajaran. Bandung: Remaja Rosdakarya, 2011.

[25] M. Nakayama, H. Yamamoto, and R. Santiago, "The Impact of Learner Characteristics on Learning Performance in Hybrid Courses among Japanese Students," Electron. J. e-Learning, vol. 5, no. 3, pp. 195-206, 2007.
[26] R. Nurislaminingsih, "Layanan Pengetahuan tentang Covid-19 di Lembaga Informasi," TIK ILMEU J. Ilmu Perpust. dan Inf., vol. 4, no. 1, pp. 19-37, 2020.

[27] Firman and S. R. Rahman, "Pembelajaran Online di Tengah Pandemi Covid-19," Indones. J. Educ. Sci., vol. 2, no. 2, pp. 81-89, 2020, doi: https://doi.org/10.31605/ijes.v2i2.659.

[28] W. He, G. Xu, and S. E. Kruck, "Online IS Education for the 21 st Century University of Technology College of Business," J. Inf. Syst. Educ., vol. 25, no. 2, pp. 101-106, 2014.

[29] N. L. Khusniyah and L. Hakim, "Efektifitas Pembelajaran Berbasis Daring," J. Tatsqif J. Pemikir. dan Penelit. Pendidik., vol. 17, no. 1, pp. 19-33, 2019, doi: https://doi.org/10.20414/jtq.v17i1.667.

[30] M. Gheytasi and H. Gowhary, "The effect of smartphone on the reading comprehension proficiency of Iranian EFL learners," Procedia - Soc. Behav. Sci., vol. 199, pp. 225-230, 2015, doi: 10.1016/j.sbspro.2015.07.510.

[31] Herlina and M. Suherman, "Potensi Pembelajaran Pendidikan Jasmani Olahraga Dan Kesehatan ( PJOK ) Di Tengah Pandemi Corona Virus Disease ( Covid ) -19 Di Sekolah Dasar," Tadulako J. Sport Sci. Phys. Educ., vol. 8, no. 1, pp. 1-7, 2020.

[32] R. H. Syah, “"'Dampak Covid-19 Pada Pendidikan Di Indonesia: Sekolah, Keterampilan, Dan Proses Pembelajaran," SALAM J. Sos. Dan Budaya Syar-I, vol. 7, no. 5, 2020, doi: https://doi.org/10.15408/sjsbs.v7i5.15314.

[33] S. Gon and A. Rawekar, "Effectivity of E-Learning through Whatsapp as a Teaching Learning Tool," MVP J. Med. Sci., vol. 4, no. 1, p. 19, 2017, doi: $10.18311 / \mathrm{mvpjms} / 0 / \mathrm{v0} / \mathrm{i0} / 8454$.

[34] R. Qomarullah, ““'Model Aktivitas Belajar Gerak Berbasis Permainan Sebagai Materi Ajar Pendidikan Jasmani (Penelitian Pengembangan Pada Siswa Kelas I Sekolah Dasar)," J. Phys. Educ. Heal. Sport, vol. 2, no. 2, pp. 76-88, 2015, doi: https://doi.org/10.15294/jpehs.v2i2.4591.

[35] M. Supriyadi, "Pelaksanaan Proses Belajar Mengajar Pendidikan Jasmani Olahraga Dan Kesehatan Pada Sekolah Dasar," J. Gelangg. Olahraga, vol. 1, no. 2, pp. 6-11, 2018.

[36] M. N. Jauhari, Sambira, and Z. Zakiah, "Dampak Pandemi Covid-19 Terhadap Pelaksanaan Pembelajaran Penjas Adaptif di Sekolah Luar Biasa," J. STAND Sport Dev., vol. 1, no. 1, pp. 63-70, 2020.

[37] P. Sun, R. J. Tsai, G. Finger, and Y. Chen, "What drives a successful e-Learning? An empirical investigation of the critical factors influencing learner satisfaction," Comput. Educ., vol. 50, pp. 1183-1202, 2008, doi: 10.1016/j.compedu.2006.11.007.

[38] S. Y. H. Sun, "Learner perspectives on fully online language learning," Distance Educ., vol. 35, no. 1, pp. 37-41, 2014, doi: 10.1080/01587919.2014.891428.

[39] N. W. Aulia and M. Aina, "Pengembangan Multimedia Interaktif Menggunakan Camtasia Studio 8 Pada Pembelajaran Biologi Materi Kultur Jaringan Untuk Siswa SMA Kelas XI MIA," BIODIK J. Ilm. Pendidik. Biol., vol. 2, no. 1 , pp. 20-26, 2016. 